\title{
SPAD index in the diagnosis of nitrogen status in cauliflower as a function of nitrogen fertilization
}

\section{Índice SPAD no diagnóstico do estado de nitrogênio de couve-flor em função da adubação nitrogenada}

\author{
Sanzio Mollica VIDIGAL ${ }^{1}$; Iza Paula de Carvalho LOPES ${ }^{2}$; Mário PUIATTI ${ }^{3}$; \\ Marcelo Resende de Freitas RIBEIRO ${ }^{4}$; Maria Aparecida Nogueira SEDIYAMA ${ }^{5}$
}

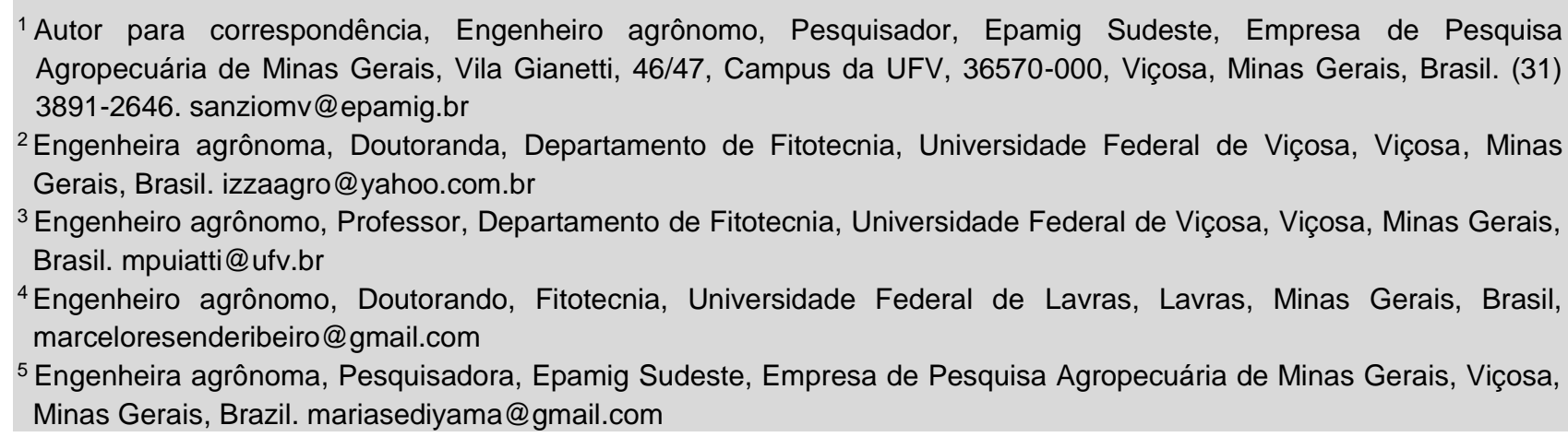

Recebido em: 23-02-2018; Aceito em: 11-05-2018

\begin{abstract}
The correct management of fertilization in cauliflower crop can be obtained by synchronizing the plant demand with the $\mathrm{N}$ supply during the crop cycle. There is no study indicating that the SPAD index can be used in the evaluation of nitrogen nutrition of cauliflower. Thus, the objective of this work was to evaluate the nitrogen nutritional status of cauliflower using the SPAD index, and curd yield as a function of nitrogen fertilization. Four rates of $\mathrm{N}$ in topdressing $\left(0,150,300\right.$, and $\left.450 \mathrm{~kg} \mathrm{ha}^{-1}\right)$ were evaluated in the experimental design of randomized blocks with four replicates. The final harvest of curds occurred from 68 to 76 days after transplanting. The first- and secondyear results showed a significant difference. Curd fresh mass showed a quadratic adjustment, with the maximum value of 1,435 and $1,611 \mathrm{~g}$, estimated with the rates of 331 and $307 \mathrm{~kg} \mathrm{ha}^{-1} \mathrm{~N}$, in the first and second year, respectively. The critical levels for leaf total $\mathrm{N}$ content were between 48.4 and $57.8 \mathrm{~g} \mathrm{~kg}^{-1}$; and for SPAD units, between 55.90 and 66.63. The nitrogen nutritional status of cauliflower can be estimated using the SPAD index. The critical level for the SPAD index and leaf $\mathrm{N}$ content varied from year to year. Higher production of cauliflower curd fresh mass can be obtained with the application of $\mathrm{N}$ rates higher than currently recommended.
\end{abstract}

Additional keywords: Brassica oleracea var. botrytis; critical level; nutritional diagnosis.

\section{Resumo}

O manejo correto da adubação na cultura da couve-flor pode ser obtido pela sincronização da demanda da planta com o suprimento de $\mathrm{N}$ durante $\mathrm{o}$ ciclo da cultura. Não há estudo que indique que o índice SPAD possa ser usado na avaliação da nutrição nitrogenada da couve-flor. Assim, objetivou-se com este trabalho avaliar o estado nutricional de nitrogênio de couve-flor utilizando o índice SPAD e a produção de inflorescências em função da adubação nitrogenada. Foram avaliadas quatro doses de $\mathrm{N}$ em cobertura $\left(0 ; 150 ; 300\right.$ e $\left.450 \mathrm{~kg} \mathrm{ha}^{-1}\right)$, no delineamento experimental de blocos ao acaso, com quatro repetições. A colheita final das inflorescências ocorreu dos 68 aos 76 dias após o transplantio. Os resultados do primeiro e do segundo anos apresentaram diferença significativa. A massa fresca da inflorescência apresentou ajuste quadrático, obtendo-se o valor máximo de 1.435 e $1.611 \mathrm{~g}$, estimado com a dose de 331 e $307 \mathrm{~kg} \mathrm{ha}^{-1}$ de N, no primeiro e do segundo anos de cultivo, respectivamente. Os níveis críticos para o teor de $\mathrm{N}$ total nas folhas situaram-se entre 48,4 e $57,8 \mathrm{~g} \mathrm{~kg}^{-1}$, e para unidades SPAD, entre 55,90 e 66,63. O estado nutricional de nitrogênio da couve-flor pode ser estimado pelo uso do índice SPAD. O nível crítico para o índice SPAD e para o teor de $\mathrm{N}$ na folha variou de um ano para o outro. Maior produção de massa fresca de inflorescência de couve-flor pode ser obtida com aplicação de doses de $\mathrm{N}$ superiores à recomendada atualmente.

Palavras-chave adicionais: Brassica oleracea var. botrytis; diagnóstico nutricional; nível crítico. 


\section{Introduction}

The proper management of fertilization in the cauliflower crop can be obtained by synchronizing the plant demand with the $\mathrm{N}$ supply during the crop cycle. Among the limiting nutrients, nitrogen $(\mathrm{N})$ deserves to be highlighted, since it is the nutrient absorbed in greater quantity by cauliflower (Castoldi et al., 2009; Takeishi et al., 2009). Moreover, the application of nitrogen fertilizers requires an adequate rate to obtain plants with curd of desired size and greater commercial acceptance.

In the field, $\mathrm{N}$ fertilization increases cauliflower yield (Camargo et al., 2008; Kano et al., 2010), but $\mathrm{N}$ shortage can result in low yield and curds of small size due to reduced leaf area (Torres et al., 2003). On the other hand, $\mathrm{N}$ fertilization does not influence cauliflower yield in intensely cultivated areas, often fertilized with nitrogen fertilizers (Kojoi et al., 2009; Mello et al., 2009).

Despite the importance of correctly performing the fertilization program in cauliflower crop, there is a discrepancy in the literature regarding the $\mathrm{N}$ rate to be applied. Some studies have demonstrated that the cauliflower responds to nitrogen fertilization up to the rate of $250 \mathrm{~kg} \mathrm{ha}^{-1} \mathrm{~N}$ (Camargo et al., 2008), and up to $300 \mathrm{~kg} \mathrm{ha}^{-1} \mathrm{~N}$ (Kano et al., 2010), while the recommendation for the state of Minas Gerais is $150 \mathrm{~kg} \mathrm{ha}^{-1}$ $\mathrm{N}$ (Vidigal \& Pereira, 2007), and 150 to $200 \mathrm{~kg} \mathrm{ha}^{-1} \mathrm{~N}$ for Sao Paulo (Trani \& Raij, 1996).

The diagnosis of $\mathrm{N}$ status is usually associated with the plant response to soil fertilization. However, this can be done directly and indirectly, using appropriately calibrated indices (Godoy et al., 2010; Fontes, 2011). The criterion most commonly used for monitoring plant $\mathrm{N}$ and $\mathrm{N}-\mathrm{NO}_{3}$ contents is the chemical analysis of leaf dry matter in the laboratory, which is a highcost, time-consuming analysis performed by qualified personnel.

Currently, in line with precision farming, indices or tests to assess $\mathrm{N}$ status need to be fast, practical, and effective (Fontes, 2011). Therefore, studies have been published using the analysis of the intensity of the green color of the plant as an index to evaluate the $\mathrm{N}$ status. This is based on the fact that $\mathrm{N}$ rates provide different intensities of green, and that the $\mathrm{N}$ status is directly correlated with the chlorophyll content or the leaf green. Thus, the green color of the leaf, represented by the chlorophyll content, which can be measured instantaneously and non-destructively by the portable meter SPAD-502, emerged as an alternative to evaluate the $\mathrm{N}$ status of the plant (Godoy et al., 2010; Fontes, 2011).

Several studies have shown that the chlorophyll content measured with SPAD-502 correlates with $\mathrm{N}$ concentration in the plant, and also with the yield of several species (Godoy et al., 2010; Moreira \& Vidigal, 2011). Notwithstanding, there is no study indicating that the use of SPAD can be considered in the evaluation of nitrogen nutrition of cauliflower. Such tests are fast, can be made in the field, and allow real-time sensing of the plant nitrogen nutritional status (Fontes, 2011); furthermore, they can become a viable alternative to the cauliflower production system.

Therefore, the objective of this work was to evaluate the nitrogen nutritional status of cauliflower using the SPAD index, and curd yield as a function of nitrogen fertilization.

\section{Materials and methods}

The experiments were conducted at the experimental farm of EPAMIG, Oratórios, Minas Gerais, from June to October 2012 and 2013. In the two years, four $\mathrm{N}$ rates $\left(0,150,300\right.$, and $\left.450 \mathrm{~kg} \mathrm{ha}^{-1}\right)$ were evaluated, and urea was used as $\mathrm{N}$ source. These rates were applied in topdressing, in three equal plots, at 14, 26, and 41 days after transplantation (DAT).

The treatments were arranged in a randomized complete block design, with four replicates. The cultivar used was Snow Mystique (TAKII), and sowing was performed, respectively, on 06/21/2012 and 06/18/2013, in 200-cell expanded polystyrene trays, filled with commercial substrate. The transplanting of the seedlings, with 3 to 4 leaves, occurred on $08 / 02 / 2012$ and $07 / 30 / 2013$, respectively, in a spacing of $0.80 \times 0.50 \mathrm{~m}$. Each experimental unit consisted of five rows, with 12 plants each, and the useful area consisted of 30 central plants of the three central rows.

The soil of the area (Red-Yellow Argisol) presented, in the $0-20 \mathrm{~cm}$ depth layer, for the two years, respectively, the following characteristics: $\mathrm{pH}$ (water) = 6.1/5.4; $\mathrm{Ca}=1.9 / 1.5 ; \mathrm{Mg}=1.2 / 0.6 ; \mathrm{Al}=0.0 / 0.1 ; \mathrm{H}+\mathrm{Al}$ $=1.98 / 2.31$, expressed in $\mathrm{cmol}_{\mathrm{c}} \mathrm{dm}^{-3} ; \mathrm{P}=$ $16.7 / 35.2 \mathrm{mg} \mathrm{dm}^{-3}$ (Mehlich 1); $\mathrm{K}=144 / 118 \mathrm{mg} \mathrm{dm}^{-3}$; and organic matter $=22 / 19 \mathrm{~g} \mathrm{~kg}^{-1}$.

Soil preparation consisted of plowing, harrowing, and opening of furrows $15 \mathrm{~cm}$ deep. Except for $\mathrm{N}$, planting fertilization, based on soil analysis and recommendations of Vidigal \& Pereira (2007), consisted of $1,500 \mathrm{~kg} \mathrm{ha}^{-1}$ single superphosphate, $80 \mathrm{~kg} \mathrm{ha}^{-1}$ potassium chloride, $20 \mathrm{~kg} \mathrm{ha}^{-1}$ borax, and $20 \mathrm{~kg} \mathrm{ha}^{-1}$ zinc sulfate. In addition, $320 \mathrm{~kg} \mathrm{ha}^{-1}$ potassium chloride was used, applied in three plots, together with the nitrogen fertilizer applications, in topdressing two years. Cultural treatments (pest control and conventional sprinkler irrigation) were applied according to the needs, following the recommendations for the crop (Vidigal \& Pereira, 2007).

In the first stage of flowering, at 40 (Year 1) and 45 (Year 2) days after transplanting, nitrogen nutritional status was evaluated by determining the green intensity and the total $\mathrm{N}$ content in the fourth leaf from the plant apex (Fontes, 2011). Leaf green color intensity was determined using the portable chlorophyll meter SPAD-502 (Soil Plant Analysis Development502), considering the average of three readings in the leaf blade (right and left border, plus leaf apex), held between 8:00 and 11:00 hours. The leaves used for 
this determination were collected and conditioned in paper bags and later placed in a forced air circulation oven at $70 \stackrel{\circ}{\circ}$ until constant mass. After drying, the dried material was ground in a Wiley mill, equipped with a 20-mesh sieve, and subjected to sulfur digestion for the determination of total $\mathrm{N}$ contents by titration after distillation in Kjeldahl microdistiller (Silva, 2009).

Harvesting occurred in the periods from 68 to 76 (Year 1) and from 63 to 73 (Year 2) DAT, and was performed by cutting the stem close to the soil. Subsequently, the following were evaluated: fresh mass of leaves, stem and curd (without leaves and with the stem cut close to the curd), by weighing the plant parts; and transverse diameter of the curd, by means of a ruler. The fresh mass of the whole plant corresponded to the sum of the fresh masses of leaves, stem and curd.

The data were submitted to analysis of variance and polynomial regression, in addition to joint analysis to evaluate the effect of Year of conduction of the experiments. The SAEG program (2007) was used at $10 \%$ probability, adjusting the model that best describes the relationship between dependent and independent variables. The critical level (CL) was estimated by associating the values of each indicator with the $\mathrm{N}$ rate that provided the maximum yield of curd (Fontes, 2011).

Using the values estimated by the mathematic model adjusted for the production of curd fresh mass, the Agronomic Efficiency of $\mathrm{N}$ (AEN) was calculated; for this, the difference between the maximum yield of curd fresh mass (YCFM), in grams, and the yield of curd fresh mass with the zero rate (YCFM zero) was used, divided by the $\mathrm{N}$ rate necessary to obtain the YCFM, i.e.: $A E N=$ (YCFM - YCFM zero) / (Rate for YCFM), according to Fontes (2011).

\section{Results and discussion}

There was a significant difference between the first- and second-year results. All evaluated characteristics were significantly influenced by the $\mathrm{N}$ rates applied in topdressing, except for the number of leaves per plant in Year 1, which ranged from 25 to 27, with a mean of 25.7 leaves per plant. Moreover, in Year 2, the number of leaves was smaller with increasing $\mathrm{N}$ rate, ranging from 14 to 18 (Figure $1 \mathrm{~A}$ ). However, the leaf fresh mass reached the maximum values of 70.63 and $82.07 \mathrm{~g}$, estimated with 370 and $306 \mathrm{~kg} \mathrm{ha}^{-1} \mathrm{~N}$, respectively, in Year 1 and Year 2 (Figure 1B). The total leaf fresh mass per plant reached a lower maximum value in Year $2(1,217 \mathrm{~g} /$ plant) compared to Year $1(1,828$ g/plant), estimated with 271 and $360 \mathrm{~kg} \mathrm{ha}^{-1} \mathrm{~N}$, respectively (Year 1: $\hat{\mathrm{Y}}=1,192.4+3.53267^{*} \times \mathrm{N}$ - $0.00491111^{*} \times \mathrm{N}^{2} ; \mathrm{R}^{2}=0.9672$, and Year 2: $\left.\hat{Y}=885.25+2.42^{\circ} \times \mathrm{N}-0.00444444^{\circ} \times \mathrm{N}^{2} ; \mathrm{R}^{2}=0.8872\right)$. However, $\mathrm{N}$ increased the mean leaf fresh mass (Figure 1B); consequently, the leaves were larger, which may have increased the leaf area and favored the photosynthetic activity.
Regarding the number of leaves, Kano et al. (2010) also did not observe response to $\mathrm{N}$ rates in topdresing up to $300 \mathrm{~kg} \mathrm{ha}^{-1} \mathrm{~N}$ for the cultivar 'Teresópolis Gigante', with 23.4 leaves per plant, on average. The difference between the number of leaves for different varieties/hybrids can be attributed to the characteristic of each cultivar, as reported by Oliveira et al. (2008); thus, nitrogen fertilization may not promote effects on this variable.

Curd fresh mass was significantly influenced by the $\mathrm{N}$ rates applied in topdressing, with maximum values of 1,435 and $1,611 \mathrm{~g}$, estimated with 331 and $307 \mathrm{~kg} \mathrm{ha}^{-1} \mathrm{~N}$, in Years 1 and 2, respectively (Figure $2 \mathrm{~A})$; these values estimate the yield of 35.87 and $40.27 \mathrm{t}$ ha $^{-1}$, respectively. The gain of curd fresh mass with $\mathrm{N}$ was $10.55 \%, 23.90 \%$, and $6.20 \%$ for 150,300 , and $450 \mathrm{~kg} \mathrm{ha}^{-1} \mathrm{~N}$, respectively, in Year 2. Hence, the higher yield of curd with higher mass in Year 2 can be attributed to the higher mean leaf fresh mass in Year 2 in relation to Year 1. In both years, there was a high correlation between the mean leaf fresh mass and the curd fresh mass $(r=0.9585, p=0.0207 ; r=0.9469, p$ $=0.0261$ ), and between the mean leaf fresh mass and the curd diameter $(r=0.9450, p=0.0275 ; r=0.9443$, $p=0.0278)$, in Year 1 and Year 2, respectively, evidencing the importance of this characteristic.

The maximum values of curd fresh mass in response to $\mathrm{N}$ application in topdressing, 1,435 and $1,611 \mathrm{~g}$, estimated with 331 and $307 \mathrm{~kg} \mathrm{ha}^{-1} \mathrm{~N}$ for 'Snow Mystique' (Figure 2A), differ from the 1,294 $\mathrm{g}$, estimated with $227 \mathrm{~kg} \mathrm{ha}^{-1} \mathrm{~N}$, 'Verona' (Oliveira et al., 2017); $1,301 \mathrm{~g}$, estimated with $300 \mathrm{~kg} \mathrm{ha}^{-1} \mathrm{~N}$, 'Teresópolis Gigante' (Kano et al., 2010); and $901 \mathrm{~g}$, estimated with $250 \mathrm{~kg} \mathrm{ha}^{-1} \mathrm{~N}$, 'Julia' (Camargo et al., 2008) for linear response; and without response to N, mean value of $791 \mathrm{~g}$ for 'Sharon' (Mello et al., 2009) and 1,730 $\mathrm{g}$ for 'Shiromaru III' (Kojoi et al., 2009). This shows the variation of the yield potential of cauliflower as a function of nitrogen fertilization.

The plant fresh mass had maximum values estimated at 3,696 and 3,087 g, with 336 and $297 \mathrm{~kg} \mathrm{ha}^{-1}$ $\mathrm{N}$, respectively (Year 1: $\hat{\mathrm{Y}}=1,884.46+10.7864^{*} \times \mathrm{N}-$ $0.0160583^{\circ} \times \mathrm{N}^{2} ; \quad \mathrm{R}^{2}=0.9699$ and Year 2: $\left.\hat{Y}=1,864.03+8.4885^{\star *}-0.0143056^{\star *} \times N^{2}=0.9994\right)$. In the same way, the maximum value of stem fresh mass was higher in Year 1 than in Year 2, with values estimated at 438 and $297 \mathrm{~g}$, with 305 and $323 \mathrm{~kg} \mathrm{ha}^{-1}$ $\mathrm{N}$, respectively (Year $1 \hat{\mathrm{Y}}=220.163+1.42608^{*} \mathrm{~N}$ - $0.00233611^{*} \mathrm{~N}^{2} ; \mathrm{R}^{2}=0.9703$ and Year 2: $\hat{Y}=157.769+0.859708^{*} \times N-0.00132917^{*} \times N^{2}$; $\left.R^{2}=0.9945\right)$.

In Year 1, it was observed that with $331 \mathrm{~kg} \mathrm{ha}^{-1}$ $\mathrm{N}$, the partition of fresh mass in the cauliflower plant was: $38.84 \%$ for curd fresh mass; $49.35 \%$ for leaf fresh mass; and $11.81 \%$ for stem fresh mass. In Year 2, with $307 \mathrm{~kg} \mathrm{ha}^{-1} \mathrm{~N}$, the observed partition of fresh mass in the cauliflower plant was: $52.22 \%$ for curd fresh mass; $38.22 \%$ for leaf fresh mass; and $9.56 \%$ for stem fresh mass, thus demonstrating higher $\mathrm{N}$ efficiency in the fresh mass partition in the plant, favoring the curd, which is the commercial part, besides the higher value of fresh mass in Year 2 (Figure 1 and 2). 
A

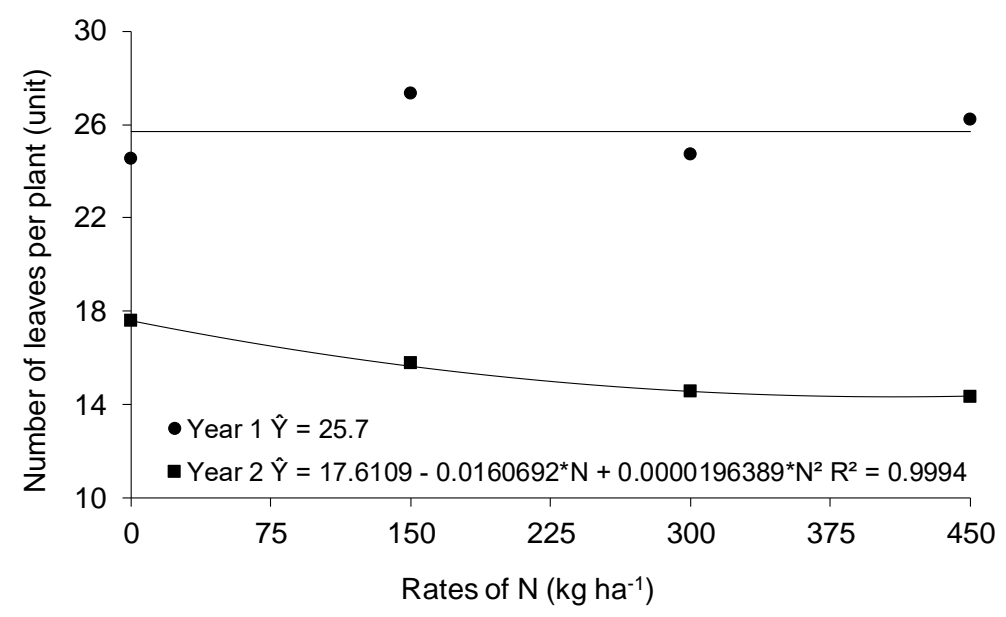

B

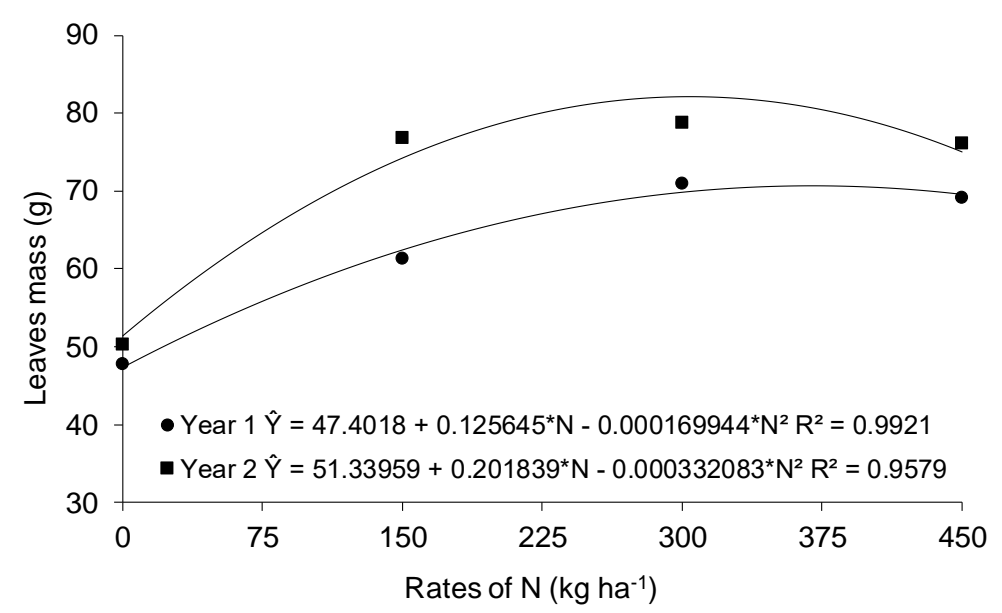

Figure 1 - Number of leaves per plant (A) and leaves fresh mass (B) of Snow Mystique cauliflower as function to nitrogen rates.

The highest efficiency can be verified by the calculation of Agronomic Efficiency (AEN), since the values of 2.91 and $2.58 \mathrm{~g} \mathrm{~kg}^{-1} \mathrm{~N}$ applied for Years 1 and 2, respectively, demonstrate the need for a smaller amount of $\mathrm{N}$ in Year 2 for the yield of curd fresh mass. The AEN values were higher than those obtained by Oliveira et al. (2017), equal to $2.53 \mathrm{~g} \mathrm{~kg}^{-1}$, and much higher than those of Camargo et al. (2008) and Kano et al. (2010), equal to 1.59 and $1.77 \mathrm{~g} \mathrm{~kg}^{-1}$, respectively.

The curd diameter reached maximum values of 23.18 and $25.13 \mathrm{~cm}$, estimated with 328 and $292 \mathrm{~kg}$ ha $^{-1} \mathrm{~N}$, respectively, in Years 1 and 2 (Figure 2B). A positive and high correlation was observed in Year $1(r$ $=0.9999, p=0.0000)$ and Year $2(r=0.9957, p=$ 0.0000 ) with the curd fresh mass, demonstrating that the higher the curd diameter, the higher the fresh mass. The maximum diameter of $21.56 \mathrm{~cm}$ was observed with the application of $225 \mathrm{~kg} \mathrm{ha}^{-1} \mathrm{~N}$, for 'Verona' (Oliveira et al., 2017). Notwithstanding, nonsignificant response to $\mathrm{N}$ fertilization has been reported for other varieties/hybrids, with the mean diameter being $20.5 \mathrm{~cm}$ for 'Teresópolis Gigante' (Kano et al., 2010), and $17.7 \mathrm{~cm}$ for 'Julia' (Camargo et al., 2008), values below the maximum obtained in this study.

In the evaluation of the nitrogen nutritional status, at 40 and $45 \mathrm{DAT}$, the total $\mathrm{N}$ content in leaf was 57.93 and $53.22 \mathrm{~g} \mathrm{~kg}^{-1}$, estimated with 307 and $450 \mathrm{~kg} \mathrm{ha}^{-1} \mathrm{~N}$, respectively (Figure $3 \mathrm{~A}$ ), and the SPAD index in the same leaf reached estimated maximum values of 66.63 and 56.63 SPAD units with 338 and $450 \mathrm{~kg} \mathrm{ha}^{-1} \mathrm{~N}$, respectively, in Years 1 and 2 (Figure $3 B$ ). Increases in leaf $N$ contents with increased $N$ dose were also found by Everaarts et al. (1996). 
A

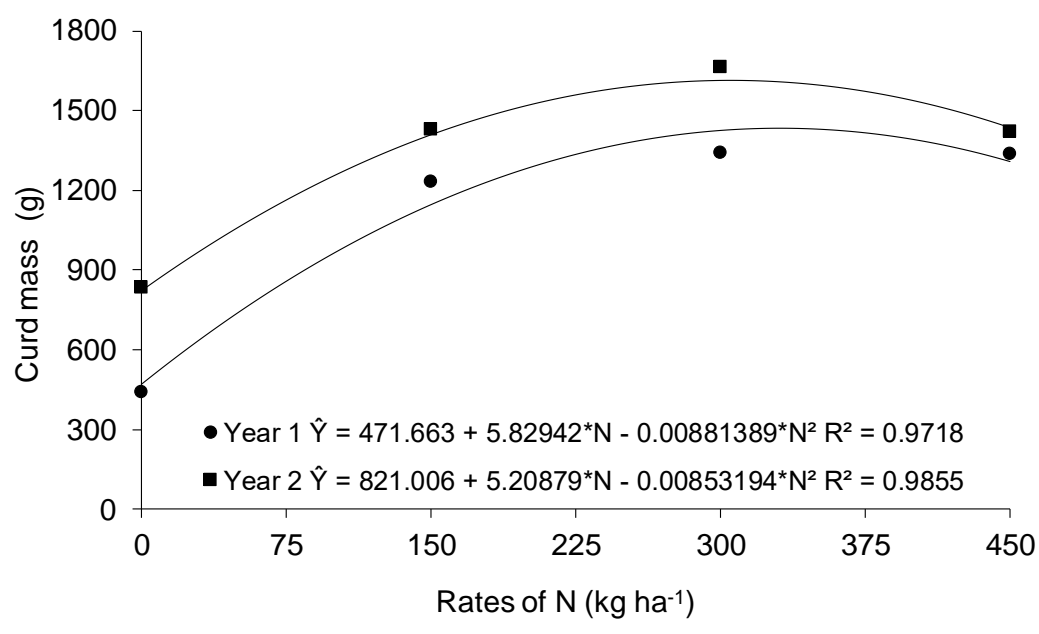

B

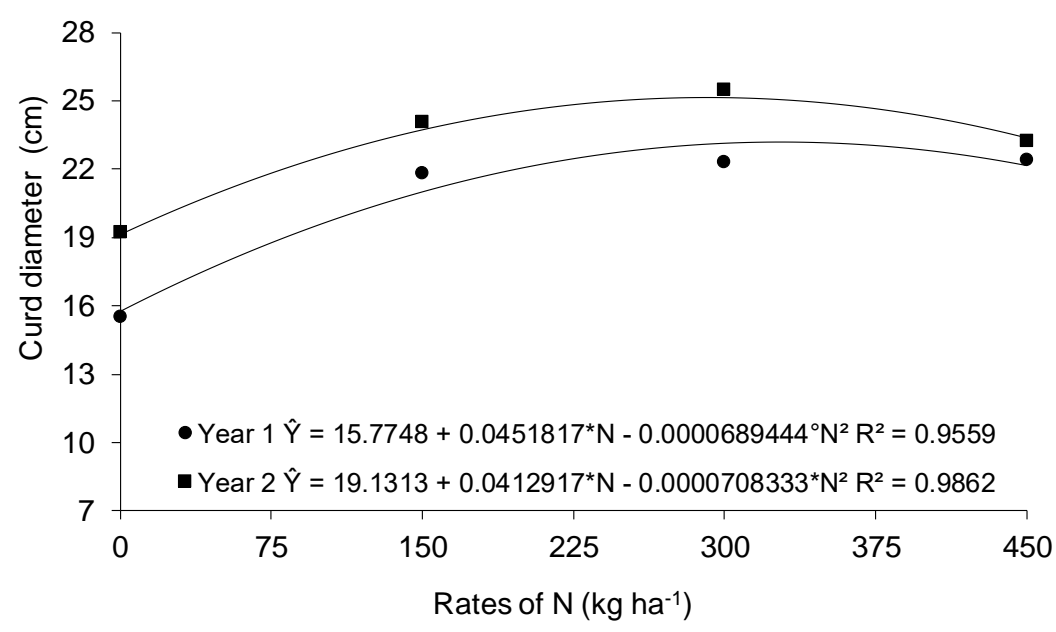

Figure 2 - Curd mass (A) and curd diameter (B) of Snow Mystique cauliflower as function to nitrogen rates.

The range considered adequate by Trani \& Raij (1996) for leaf $\mathrm{N}$ content in cauliflower is 40 to 60 $\mathrm{g} \mathrm{N} \mathrm{kg}{ }^{-1}$ leaf dry mass. The maximum values of $\mathrm{N}$ in leaf $\left(57.93\right.$ and $\left.53.22 \mathrm{~g} \mathrm{~kg}^{-1}\right)$ are within this range, and adequate values were observed from the application of 30 and $158 \mathrm{~kg} \mathrm{ha}^{-1} \mathrm{~N}$, respectively, in Years 1 and 2.

In complete nutrient solution, Bianco et al. (2015) observed a leaf $\mathrm{N}$ content equal to $44.2 \mathrm{~g} \mathrm{~kg}^{-1}$, while in $\mathrm{N}$-free solution, $\mathrm{N}$ contents were $8.8 \mathrm{~g} \mathrm{~kg}^{-1}$ (old leaves), $12.8 \mathrm{~g} \mathrm{~kg}^{-1}$ (intermediate leaves), and $27.7 \mathrm{~g} \mathrm{~kg}^{-1}$ (young leaves) for the hybrid 'Verona'. In this study, the control treatment $\left(0 \mathrm{~kg} \mathrm{ha}^{-1} \mathrm{~N}\right)$ showed leaf $\mathrm{N}$ content of 36.03 and $27.31 \mathrm{~g} \mathrm{~kg}^{-1}$, respectively, in Year 1 and Year 2 (Figure 3A), below the appropriate range (Trani \& Raij, 1996). It is noteworthy that in the control, we observed characteristic symptoms of $\mathrm{N}$ deficiencies, such as purple coloration followed by yellowing of older leaves (Bianco et al., 2015), in addition to lower plant growth, which led to the yield of curd with low fresh mass in both years. Reduction of growth is a major effect caused by $\mathrm{N}$ deficiency in plants (Avalhães et al., 2009; Taiz \& Zaiger, 2010).

The SPAD index that measures green color intensity may vary according to species, genotype, growth stage, leaf age, growing season, deficiency or excess of other nutrients, among other factors (Fontes, 2011). In this work, with the hybrid 'Snow Mystique', values between 56.34 and 66.63 were observed at the rates of 0 and $331 \mathrm{~kg} \mathrm{ha}^{-1} \mathrm{~N}$ (Year 1), and values between 47.90 and 55.90 at the rates of 0 and $307 \mathrm{~kg} \mathrm{ha}^{-1} \mathrm{~N}$ (Year 2), (Figure 3B). Nonetheless, the critical level values with the portable meter SPAD-502 are shown to be variable, requiring adjustment for each situation, such as nutrient deficiency, environmental conditions, variety, and stage of crop growth (Godoy et al., 2010; Fontes, 2011). 
A

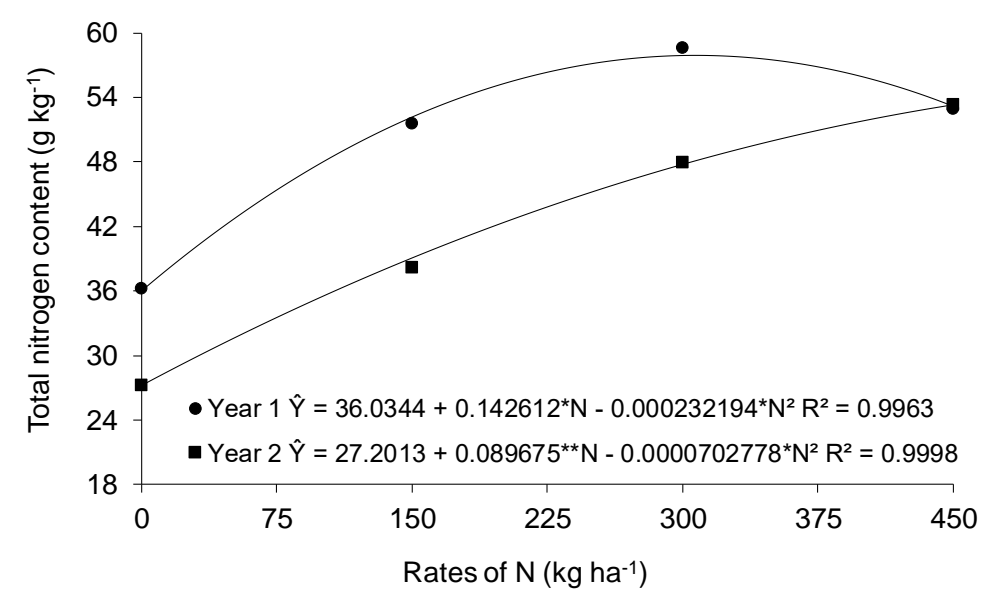

B

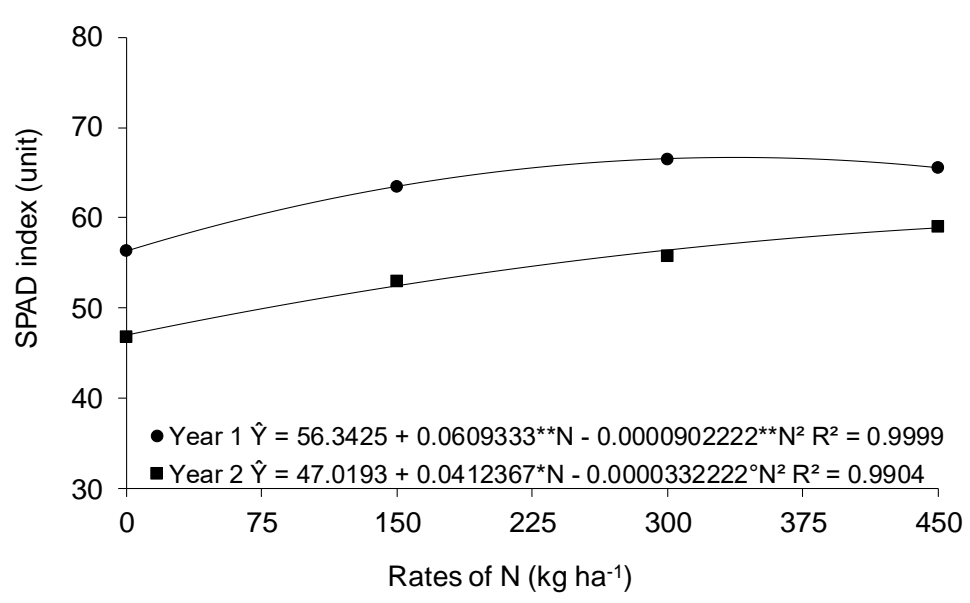

Figure 3 - Total nitrogen content in leaf (A) and SPAD index (B) of Snow Mystique cauliflower as function to nitrogen rates.

There was a high correlation between the SPAD index and the $\mathrm{N}$ content for Year 1: $r=0.9873, \mathrm{p}$ $=0.0063$, and for Year 2: $r=0.9940, p=0.0001$ (Table 1). Thus, this result indicates the possibility of using the portable meter SPAD-502 in the indirect evaluation of leaf $\mathrm{N}$ content for the characterization of nitrogen nutritional status in cauliflower plants. For this, the following equation was adjusted: Total $\mathrm{N}$ content $=-79.692+$ $2.0578^{\star *}$ SPAD, $R^{2}=0.9748$ (Year 1), and Total $\mathrm{N}$ content $=-74.9683+2.175895^{\star \star} \mathrm{SPAD}, \mathrm{R}^{2}=0.9877$
(Year 2). The critical levels, estimated with the $\mathrm{N}$ dose for maximum curd fresh mass, were 57.80 and $48.41 \mathrm{~g}$ $\mathrm{kg}^{-1}$ for the total $\mathrm{N}$ content and 66.63 and 55.90 SPAD units, respectively, in Years 1 and 2 (Figure 3B). In the cabbage crop, critical levels varied throughout the cycle: $62.9 ; 60.3$; and $59.0 \mathrm{~g} \mathrm{~kg}^{-1}$ for total $\mathrm{N}$ content, and 60.8; 58.4; and 53.5 SPAD units, respectively, at 50; 64; and 78 days after sowing (Moreira \& Vidigal, 2011).

Table 1 - Pearson's correlation coefficients between SPAD index and total N content in the fourth leaf at 40 and 45 days after transplanting (DAT) with curd fresh mass of cauliflower Snow Mystique as a function of nitrogen rates.

\begin{tabular}{lccc}
\hline \multirow{2}{*}{ Characteristics } & Total N content & SPAD index & Curd fresh mass \\
\cline { 2 - 4 } & \multicolumn{3}{c}{ Year 1 (40 DAT $)$} \\
\hline SPAD index & $0.9873(p=0.0063)$ & --- & $0.9852(p=0.0074)$ \\
Total N content & -- & $0.9873(p=0.0063)$ & $0.9671(p=0.0165)$ \\
\hline & & Year 2 (45 DAT $)$ \\
\hline SPAD index & $0.9940(p=0.0000)$ & -- & $0.8415(p=0.0793)$ \\
Total N content & -- & $0.9940(p=0.0000)$ & $0.8552(p=0.0724)$ \\
\hline
\end{tabular}


There was a correlation of the total $\mathrm{N}$ content and SPAD index with the yield of cauliflower curd fresh mass (Table 1). High correlations between these characteristics, especially the SPAD index, are very important in the diagnosis of $\mathrm{N}$.

It should be noted that the highest demand for $\mathrm{N}$ by cauliflower occurs in the period from 30 to 67 DAT (Takeishi et al., 2009; Castoldi et al., 2009; Alves et al., 2011). The high correlation of the SPAD index in the season of higher demand for $\mathrm{N}$ is important in the management of nitrogen fertilization for cauliflower, since it allows the use of SPAD in the evaluation of $N$ nutritional status for the crop. Moreover, it must be taken into account that the criterion to monitor the plant $\mathrm{N}$ levels is the chemical analysis of leaf dry matter in the laboratory, and that such analyses are expensive, time consuming, and performed by qualified personnel. The SPAD index, which instantaneously and nondestructively measures the green color of the leaf, represented by the chlorophyll content, is consolidated as an alternative to evaluate $\mathrm{N}$ content. $\mathrm{A}$ high positive correlation between SPAD index and leaf $\mathrm{N}$ content for cabbage, was obtained by Moreira \& Vidigal (2011), as has been observed for other crops (Fontes, 2011; Porto et al., 2011; Porto et al., 2014).

In Year 2, the variables curd fresh mass, total leaf mass, plant fresh mass, average leaf fresh mass, and diameter had the maximum point estimated with lower $\mathrm{N}$ rates in relation to Year 1. An explanation for this would be the residual effect of $\mathrm{N}$ applied in Year 1, since both experiments were conducted in the same area to maintain the gradient of soil $\mathrm{N}$ availability. Therefore, the amount of $\mathrm{N}$ required in the subsequent cultivation was lower for obtaining better results. Notwithstanding, low residual effect of nitrogen fertilization, as a function of the soil $\mathrm{N}$ transformation dynamics, was observed by Cardoso Neto et al. (2006) after melon cultivation with the application of $80 \mathrm{~kg} \mathrm{ha}^{-1}$ $\mathrm{N}$. According to the authors, the amounts of $\mathrm{N}$ accumulated in the soil are not enough to meet the needs of the crops that will be cultivated in the same area.

It is noteworthy that the residual effect of nitrogen fertilization may vary with the soil type and amount of $\mathrm{N}$ applied. The $\mathrm{N}$ rate used by Cardoso Neto et al. (2006), in Quartzarenic Neosol, was much lower than those used in this work, in Red-Yellow Argisol. The N mineralization potential varies with the soil type and its different carbon contents (Kliemann \& Malavolta 1993), resulting in different $\mathrm{N}$ availability and, consequently, differences in response and yield curves of different crops.

The amount of $\mathrm{N}$ required to estimate the maximum values of the various variables shows that the yield potential of cauliflower responds to $\mathrm{N}$ rates above that recommended for Minas Gerais, which is $150 \mathrm{~kg} \mathrm{ha}^{-1} \mathrm{~N}$ (Vidigal \& Pereira, 2007), and São Paulo, which is 150 to $200 \mathrm{~kg} \mathrm{ha}^{-1} \mathrm{~N}$ (Trani \& Raij, 1996), and above the values of 250 and $300 \mathrm{~kg} \mathrm{ha}^{-1} \mathrm{~N}$ found by Camargo et al. (2008) and Kano et al. (2010), respectively. Furthermore, lack of response to $\mathrm{N}$ fertilization was observed by Kojoi et al. (2009); Mello et al. (2009). However, these differences in the response to nitrogen fertilization can be attributed to climatic conditions, soil type, varieties/hybrids, growing season, among others. This confirms that in the management of nitrogen fertilization, which is the nutrient most absorbed by cauliflower (Takeishi et al., 2009; Castoldi et al., 2009), the genetic material, growing season, and soil type should be considered.

\section{Conclusions}

The nitrogen nutritional status of cauliflower can be estimated using the SPAD index

The critical level for SPAD index and leaf $\mathrm{N}$ content varied from year to year.

Greater yield of cauliflower curd fresh mass can be obtained with the application of $\mathrm{N}$ rates higher than currently recommended.

\section{Acknowledgements}

To FAPEMIG, both for granting the BIPDT scholarship to the first author and for the financial support.

\section{References}

Alves AU, Prado RM, Correia MAR, Gondim ARO, Cecílio Filho, AB, Politi LS (2011) Couve-flor cultivada em substrato: marcha de absorção de macronutrientes e micronutrientes. Ciência e Agrotecnologia 35 (1):4555.

Avalhães CC, Prado RM, Correia MAR, Rozane DE, Romualdo LM (2009) Avaliação do estado nutricional de plantas de couve-flor cultivadas em solução nutritiva suprimidas de macronutrientes. Nucleus 6 (1):250261.

Bianco MS, Cecílio Filho AB, Carvalho LB (2015) Nutritional Status of the Cauliflower Cultivar 'Verona' Grown with Omission of out Added Macronutrients. PLOS ONE 10 (4): 1-17.

Camargo MSD, Mello SDC, Foltran DE, Carmello QADC (2008) Produtividade e podridão parda em couve-flor de inverno influenciadas pelo nitrogênio e boro. Bragantia 67 (2): 371-375.

Cardoso Neto F, Guerra HOC, Chaves LHG (2006) Nitrogênio residual em solo adubado com diferentes fontes e intervalos de aplicação de nitrogênio. Caatinga 19 (2):161-168.

Castoldi R, Charlo HCO, Vargas PF, Braz LT (2009) Crescimento, acúmulo de nutrientes e produtividade da cultura da couve-flor. Horticultura Brasileira 27 (4):438-446.

Everaarts AP, De Moel CP, Van Noordwijk M (1996) The effect of nitrogen and method of application on nitrogen uptake of cauliflower and on nitrogen in crop residues and soil at harvest. Netherlands Journal of Agricultural Sciences 44 (1):43-55. 
Fontes PCR (2011) Nutrição mineral de plantas: avaliação e diagnose. Viçosa: Arka Editora. 296p.

Godoy LJG, Souza TR, Villas Bôas (2010) Perspectivas de uso de métodos diagnósticos alternativos: análise da seiva e medida indireta da clorofila. In: Prado RM, Cecílio Filho AB, Correia MAR, Puga AP (ed) Nutrição de plantas: diagnose foliar em hortaliças. FCAV/CAPES/FAPESP/FUNDUNESP. p.135-184.

Kano C, Salata AC, Higuti ARO, Godoy AR, Cardoso All, Evangelista RM (2010) Produção e qualidade de couve-flor cultivar Teresópolis Gigante em função de doses de nitrogênio. Horticultura Brasileira 28 (4):453-457 .

Kliemann HJ, Malavolta E (1993) Disponibilidade de enxofre em solos brasileiros. I. Avaliação dos potenciais de mineralização de nitrogênio e enxofre por incubação aberta. Anais da Escola de Agronomia e Veterinária 23(1):129-144.

Kojoi C, Mello SDC, Camargo MSD, Fagan EB, Ribeiro MF (2009) Adubação com nitrogênio e boro na incidência de hastes ocas e na produção de couve-flor. Ciência e Agrotecnologia 33 (1):13-17.

Mello SC, Camargo MS, Vivian R, Nascimento TS, Oliveira ES, Bertanha R (2009) Nitrogênio e boro na produção e incidência de haste oca em couve-flor 'Sharon'. Bragantia 68 (3):761-764.

Moreira MA, Vidigal SM (2011) Evolução das características da planta associadas à nutrição nitrogenada de repolho. Revista Ceres 58 (2):243-248.

Oliveira ACB, Sediyama MAN, Pedrosa MW, Garcia NCP, Garcia SLR (2008) Divergência genética e descarte de variáveis em alface cultivada sob sistema hidropônico. Acta Scientiarum. Agronomy 26 (2): 211217.
Oliveira FC, Almeida ACS, Geisenhoff LO, Lima Junior JA, Niz AIS (2017) Effects of top-dressing nitrogen levels on the productivity of cauliflower. Científica 45 (2): 190-196.

Porto ML, Puiatti M, Fontes PCR, Cecon PR, Alves JC, Arruda, JA (2011) Índice SPAD para diagnóstico do estado de nitrogênio na cultura de abobrinha. Horticultura Brasileira 29 (3): 311-315.

Pôrto MLA, Puiatti M, Fontes PCR, Cecon PR, Alves JC (2014) Índice SPAD para o diagnóstico do estado de nitrogênio na cultura do pepino japonês em ambiente protegido. Horticultura Brasileira 32 (3): 292296.

SAEG (2007) Sistema para Análise Estatística. Versão 9.1. Fundação Artur Bernardes.

Silva FC (2009) Manual de análises de solos, plantas e fertilizantes. Embrapa Informação Tecnológica, 627 p.

Taiz L, Zeiger E (2010) Plant Physiology. Sinauer Associates. 782p.

Takeishi J, Cecílio Filho AB, Oliveira PR (2009) Crescimento e acúmulo de nutrientes em couve-flor 'Verona'. Bioscience Journal 25 (4):1-10.

Torres JLR, Fabian AJ, Pocay VG (2003) Níveis de adubação nitrogenada nas características morfológicas e produtivas do jiló. Horticultura Brasileira 21 (2):167- $\quad-170$.

Trani PE, Raij BV (1996) Hortaliças. In: Raij BV, Cantarella H, Quaggio JA, Furlani AMC (ed) Recomendação de adubação e calagem para o Estado de São Paulo. 2ed. Fundação IAC. p.157-185.

Vidigal SM, Pereira PRG (2007) Couve-flor. In: Paula Júnior TJ, Venzon M (ed) 101 Culturas: manual de tecnologias agrícolas. EPAMIG. p.301-304. 